\title{
Correlation between Hydrolytic Enzymes Activity, Geographical Origin and Pathogenicity of Some Isolates of Fusarium oxysporum f. sp. albedinis
}

\author{
Sidaoui Abouamama ${ }^{1 *}$, Karkachi Noureddine ${ }^{1}$, Bertella Anis ${ }^{1}$, Terbeche Ryme ${ }^{1}$, El Goumi Younes ${ }^{2}$, Chhiba \\ Mostafa $^{2}$ and Kihal Mebrouk ${ }^{1}$
}

${ }^{1}$ Laboratory of Applied Microbiology, Department of Biology, University of Oran 1 (Ahmed Ben Bella), Algeria

${ }^{2}$ Faculty of Science and Technology of Settat Hassan $1{ }^{\text {st }}$ University -Morocco

*Corresponding author: Sidaoui Abouamama, Laboratory of Applied Microbiology, Department of Biology. University of Oran 1 (Ahmed BenBella), Algeria.
Received Date: September 24, 2018

Published Date: October 05, 2018

\begin{abstract}
The 20 isolates of Fusarium oxysporum f. sp. albedinis (Foa) produce amylase and cellulase enzymes, with the development of lysis zones around the inoculum (clear region) on the selective medium, indicates starch hydrolysis and cellulose degradation, with a variation in the ability of the isolates to produce these two enzymes, and this after measuring the diameters of the lysis zone. After Principal Component Analysis (PCA), we found that there is a strong positive correlation between mortality rate and amylolytic activity $\mathrm{CP}_{1}(74.80 \%)$ on the one hand and a weak correlation with cellulase $\mathrm{CP}_{2}(22.3 \%)$, on the other hand. While, there is no correlation between the pathogenicity of the isolates and the geographical origin of the isolate or cultivar from which this isolate was isolated $\mathrm{P}=0.3042$.
\end{abstract}

Keywords: Amylase; Cellulase; Fusarium oxysporum f. sp. albedinis

\section{Introduction}

The blessed tree mentioned in the Qur'an, symbol of life in arid and semi-arid regions, The date palm Phoenix dactylifera L. is a monocotyledon dioecious plant, belongs to the family of Arecaceae [1-3]. Which includes 200 genera and more than 2500 species, this plant is cultivated for more than 4000 years, and the genus includes about 14 species distributed in the desert, tropical and subtropical zone of the globe [4-6]. Date palm has long been recognized as one of the most important resources of arid and saharan habitats, because they represent an ecological, economic and social importance considerable for many countries in the arid zones, which are among the poorest in the world. Indeed, date palms widely cultivated for: first, its multiple uses and its ecosystem services, especially for its comestibles fruits and constitute the principal financial resources of oasis cultivators, and second, for its ability to adapt to the conditions of the most severe arid climates, who contributes to the development of subjacent (cereals, fodder, vegetables, tomato, saffron and fruit trees cultures), constitute the main axis of agriculture in the desert regions and allowing the development of various forms of animal and plant life essential for the maintenance and survival of desert populations $[7,2,8]$.

In Algeria, date palm Phoenix dactylifera L. is the essential component of the oasis ecosystem. It is cultivated at the level of 16 provinces with a surface of 120830 hectares, Thus, Algeria is ranked 4th in the world and first in the Maghreb, with about $18,605,100$ palms, whose productive potential is $9,641,680$ tons. In these regions, palm is considered as fortune of the most important economic resources, and this offers numerous benefits to the population of desert areas, especially in social terms. However, in recent years the date production has experienced a significant decline principally due to vascular fusariosis, known locally as Bayoud caused by a soil fungus Fusarium oxysporum f. sp. albedinis (Foa) [3]. It is considered one of the most serious diseases, which poses a permanent threat to the palm groves of North Africa and leads to the disappearance of 20 million palm trees, including three million Algerian palm trees, ever since 1870 [8-10]. In most of the infested oases, the Bayoud has made disappeared the best variety 
such as Boufeggous, Medjhoul in Morocco and Deglet Nour in some oases in the south of Algeria [11].

The objective of this work is to study the correlation between the activity of hydrolytic enzymes and the pathogenicity of some isolates of Fusarium oxysporum f. sp. albedinis on the one hand, and the correlation between the geographic origin and the pathogenicity of these isolates on the other hand.

\section{Material and Methods}

\section{Isolation of pathogenic fungi}

The isolates of Foa used in this study ware isolated in our previous work [12,13].

\section{Amylase activity of Fusarium oxysporum f.sp. albedinis}

The search for the amylolytic activity of our isolates was carried out on a starch-based medium, according to the method described by [14]. An explant of $0.5 \mathrm{~cm}$ of diameter of each isolate was deposited in the center of a Petri dish containing the PSA medium at $\mathrm{pH} 5$, supplemented with $1 \%$ soluble starch. The dishes are then incubated at $30^{\circ} \mathrm{C}$. for 24 to 72 hours. After incubation, a solution of lugol was sprayed on the surface of the dich, the background of the medium appears blue and clear halos appear around of the colony, witnesses an amylolytic activity [15-17]. The diameter of the lysis zones was measured for the three repetitions that have been performed.

\section{Cellulosic activity of Fusarium oxysporum f.sp. albedinis}

The most reliable technique for demonstrating cellulase activity is to show the ability of isolates to assimilate cellulose, on a solid medium based on cellulose, whose composition is as follows: $\mathrm{NaNO}_{3}(2 \mathrm{~g}), \mathrm{K}_{2} \mathrm{HPO}_{4}(1 \mathrm{~g}), \mathrm{MgSO}_{4}, \mathrm{H}_{2} \mathrm{O}(1 \mathrm{~g}), \mathrm{KC}(10.5 \mathrm{~g}), \mathrm{ZnSO}_{4}, \mathrm{H}_{2} \mathrm{O}$ (0.005g), $\mathrm{CuS}_{4}, 5 \mathrm{H}_{2} \mathrm{O}(0.001 \mathrm{~g}), \mathrm{MnCl}_{2}(0.001 \mathrm{~g})$, Cellulose (Carboxyl), methylcellulose) (2.5g), agar (30g), $1000 \mathrm{ml}$ of distilled water, $\mathrm{pH}$ $=5[18,19]$. For this we deposited an explant of $0.5 \mathrm{~cm}$ of diameter of each isolate in the center of a Petri dish containing the cellulosebased medium and incubated at $30{ }^{\circ} \mathrm{C}$ for 2 to 3 days. After incubation, a solution of Congo Red was then poured into each Petri dish; the dishes were then treated with a flooding with $1 \mathrm{M} \mathrm{NaCl}$ for 15 minutes. The degradation of the cellulose is visualized after the appearance of a clear zone around of the fungal colony $[15,16,20]$.

\section{Correlation between pathogenicity and the two enzymes}

Correlation between pathogenicity and amylase and cellulase was analyzed by the analysis of Principal Component Analysis (PCA) by the JMP software (SAS Pro (JMP®, Version <12>. SAS Institute Inc., 2015). The principle of this method was to find the axes that best represent the correlation of the isolates in the multidimensional space of the three parameters (mortality rate, amylase and cellulase).

\section{Histological studies}

The induction of the disease and the reproduction of the symptoms attest to the belonging of the inoculated isolates to the special form albedinis. At the end of the trial, and to confirm the infection of the young seedlings by Foa, we considered it useful to carry out transverse and longitudinal histological sections of the roots after a month of inoculation.

\section{Results}

\section{Amylase activity of Fusarium oxysporum f.sp. albedinis}

The 20 isolates were developed lysis zones (clear region) on the selective medium, indicated the hydrolysis of the starch, with varied amylolytic activity between the isolates after the measurement of the diameter of the zones formed (Figure 1 \& Table 1).
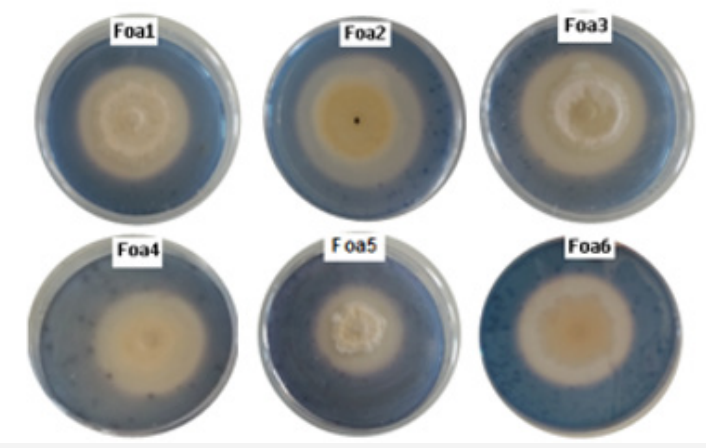

Figure 1: Amylase production on agar medium; the clear region around each colony indicates an Amylolytic activity and the zone of hydrolysis of starch by the isolates of Foa.

Table 1: Diameters of amylolytic activity of Foa.

\begin{tabular}{|c|c|c|c|c|c|}
\hline Isolâtes & $\mathrm{D}_{1}$ & $\mathrm{D}_{2}$ & $\mathbf{D}_{3}$ & Means & M \% \\
\hline $\mathrm{M}_{15 \mathrm{~A}_{1}}$ & 1,2 & 1,4 & 1,4 & 1,33 & 96 \\
\hline M15G & 1,5 & 1,3 & 1,5 & 1,43 & 72 \\
\hline $\mathrm{M}_{15 D_{1}}$ & 1,2 & 1,5 & 1,4 & 1,37 & 80 \\
\hline B15H & 1,8 & 1,6 & 1,5 & 1,63 & 100 \\
\hline M15H & 1,1 & 0,8 & 1 & 0,97 & 52 \\
\hline $\mathrm{T}_{15} \mathrm{H}_{1}$ & 1,3 & 1,6 & 1,5 & 1,47 & 76 \\
\hline A15T & 1 & 1,3 & 1 & 1,10 & 84 \\
\hline $\mathrm{T} 15 \mathrm{H}$ & 1,3 & 1,4 & 1,6 & 1,43 & 96 \\
\hline M15T & 1,2 & 1 & 1 & 1,07 & 53 \\
\hline $\mathrm{M}_{15 \mathrm{~T}_{1}}$ & 2 & 1,8 & 2,1 & 1,97 & 80 \\
\hline B15F & 1,4 & 1,7 & 1,5 & 1,53 & 96 \\
\hline T15D & 1,7 & 1,5 & 1,5 & 1,57 & 100 \\
\hline M15D & 1,1 & 1,3 & 1 & 1,13 & 92 \\
\hline 015T & 0,6 & 0,8 & 0,4 & 0,60 & 44 \\
\hline I08G & 1,6 & 1,3 & 1,5 & 1,47 & 92 \\
\hline $\mathrm{M}_{15 \mathrm{D}_{2}}$ & 1,2 & 1,4 & 1,2 & 1,27 & 76 \\
\hline M15A & 1 & 0,8 & 0,8 & 0,87 & 44 \\
\hline $\mathrm{M}_{15 \mathrm{~A}_{2}}$ & 0,7 & 0,7 & 0,5 & 0,63 & 44 \\
\hline $\mathrm{O} 15 \mathrm{H}$ & 1,2 & 1 & 1,3 & 1,17 & 88 \\
\hline 015D & 1,1 & 0,8 & 1,4 & 1,10 & 52 \\
\hline
\end{tabular}

$\mathrm{D}_{1}-\mathrm{D}_{3}$ : Diametre $(\mathrm{cm})$

$\mathrm{M} \%$ : Mortality rate in \%

\section{Cellulosic activity of Fusarium oxysporum f.sp. albedinis}

Hydrolytic enzymatic activity showed that all Foa isolates were able to produce cellulose, the cellulose degradation after incubation was observed by the development of lysis zones (light halo) on the selective medium. We noted that there is variation in the ability of 
isolates to produce cellulase after measuring the diameters of the lysis zone (Figure 2 \& Table 2).
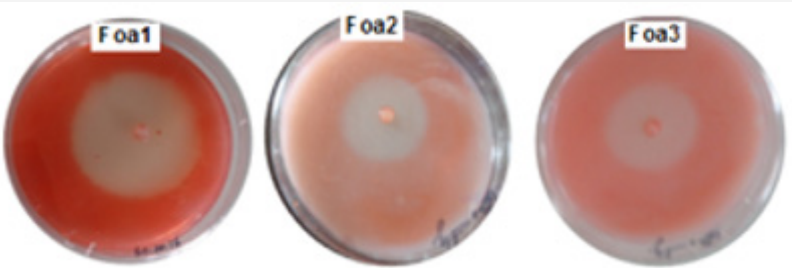

Figure 2: Cellulosic activity of some isolates of Foa.

Table 2: Diameters of Cellulosic activity of Foa.

\begin{tabular}{|c|c|c|c|c|c|}
\hline Isolates & $D_{1}$ & $\mathrm{D}_{2}$ & $\mathrm{D}_{3}$ & Means & М\% \\
\hline $\mathrm{M}_{15 A_{1}}$ & 4,4 & 4,2 & 3,9 & 4,17 & 96 \\
\hline M15G & 3 & 2,7 & 3,2 & 2,97 & 72 \\
\hline $\mathrm{M}_{15 D_{1}}$ & 3,2 & 2,8 & 3 & 3,00 & 80 \\
\hline B15H & 4,7 & 4,3 & 4,5 & 4,50 & 100 \\
\hline M15H & 3,1 & 2,8 & 2,7 & 2,87 & 52 \\
\hline $\mathrm{T} 15 \mathrm{H}_{1}$ & 3,9 & 3,6 & 3,8 & 3,77 & 76 \\
\hline A15T & 2,1 & 1,7 & 2,3 & 2,03 & 84 \\
\hline $\mathrm{T} 15 \mathrm{H}$ & 3,4 & 3,4 & 3,6 & 3,47 & 96 \\
\hline M15T & 2,2 & 2,5 & 2,3 & 2,33 & 53 \\
\hline $\mathrm{M}_{15 \mathrm{~T}_{1}}$ & 2 & 1,8 & 2,1 & 1,97 & 80 \\
\hline B15F & 3,4 & 3,5 & 3,2 & 3,37 & 96 \\
\hline T15D & 4,1 & 4,3 & 4,1 & 4,17 & 100 \\
\hline M15D & 2,5 & 2,3 & 2,3 & 2,37 & 92 \\
\hline $015 \mathrm{~T}$ & 0,6 & 0,8 & 0,4 & 0,60 & 44 \\
\hline I08G & 3,3 & 3 & 3,1 & 3,13 & 92 \\
\hline $\mathrm{M}_{15 D_{2}}$ & 3,2 & 3,4 & 4,2 & 3,60 & 76 \\
\hline M15A & 1 & 0,8 & 0,8 & 0,87 & 44 \\
\hline $\mathrm{M}_{15 A_{2}}$ & 3,1 & 3,3 & 3,5 & 3,30 & 44 \\
\hline $\mathrm{O} 15 \mathrm{H}$ & 2,9 & 3,4 & 3,3 & 3,20 & 88 \\
\hline 015D & 4,1 & 3,8 & 4,4 & 4,10 & 52 \\
\hline
\end{tabular}

$\mathrm{D}_{1}-\mathrm{D}_{3}$ : Diametre $(\mathrm{cm})$

$\mathrm{M} \%$ : Mortality rate in \%

\section{Histological studies}

Our microscopic observations on the anatomy and morphology as well as, the histochemical reactions in the roots of the seedlings palms, firstly made it possible to highlight and confirm the characteristics of the anatomical structures of the roots, and then showed that the periphery of these roots was characterized by brown spots, resulting accumulation of phenolic compounds occurred in date palm callus in response to the infection by Foa. The secretion of polyphenols represents an important role in the resistance process against Foa (Figure 3 \& Table 3).

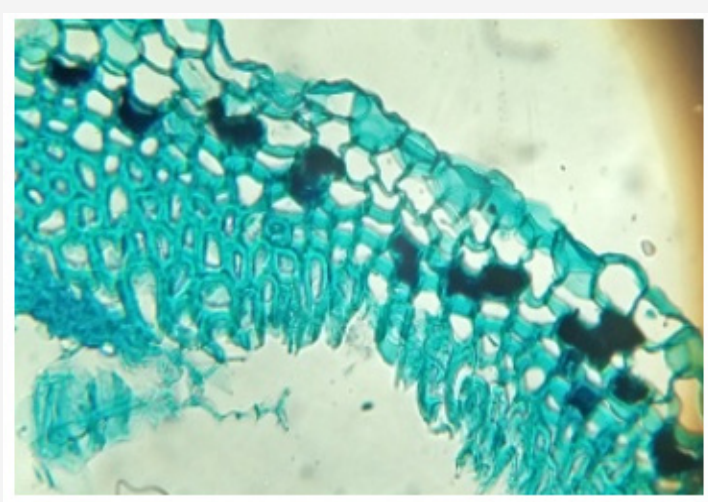

Figure 3: Microscopic observation of transversal histological sections showed mycelial through the bark and intercellular space occupation and the secretion of phenolic compounds in the root periphery.

Table 3: Main components calculated with correlations (proper values).

\begin{tabular}{|c|c|c|c|}
\hline Number & proper Values & Percentage & $\begin{array}{c}\text { Cumulative } \\
\text { Percentage }\end{array}$ \\
\hline 1 & 22,440 & 74,801 & 74,801 \\
\hline 2 & 0,6701 & 22,336 & 97,137 \\
\hline 3 & 0,0859 & 2,863 & 100,000 \\
\hline
\end{tabular}

\section{Correlation between the two enzymes, geographical origin and the pathogenicity}

We noted that there is a strong positive correlation between mortality rate and amylolytic activity and low correlation with cellulose. Our results are explained by two main components (Figure 4), the first main component $\mathrm{CP}_{1}(74,80 \%)$, is more correlated with mortality rate and amylase activity (Table 3 ), this suggests that these two variables vary together if one increases, the other tends to increase. This $\mathrm{CP}_{1}$ can be considered as a measure of the mortality rate $(0,63)$ and the amylase activity $(0,62)$ (Table 4$)$. The second main component $\mathrm{CP}_{2}(22,3 \%)$, is strongly correlated with cellulase activity $(0,89)$ (Figure 4$)$, it only augment with the augmentation in cellulase activity, This $\mathrm{CP}_{2}$ can be considered as a measure of cellulase activity (Figure $4 \&$ Table 4 ).

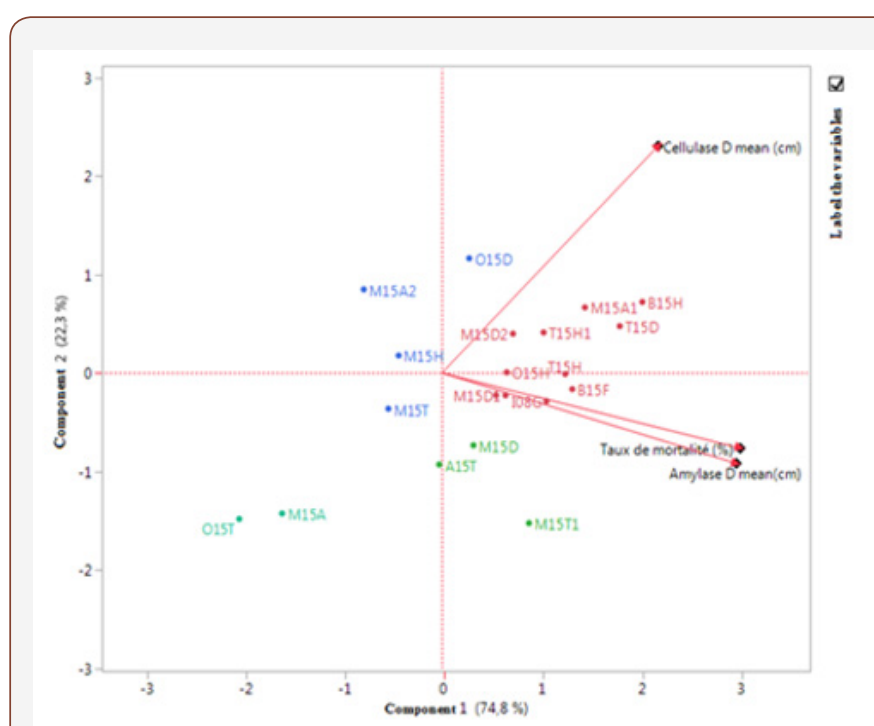

Figure 4: Main components correlates the three parameters. 
Table 4: Main components calculated with correlations (proper vectors).

\begin{tabular}{|c|c|c|c|}
\hline & Main 1 & Main 2 & Main 3 \\
\hline Mortality rate (\%) & 0,63 & $-0,29$ & $-0,71634$ \\
\hline Amylase D mean (cm) & 0,62 & $-0,35$ & 0,69662 \\
\hline Cellulase D mean (cm) & 0,46 & 0,89 & 0,03970 \\
\hline
\end{tabular}

Levels not connected by same letter not significantly different at $\mathrm{P}=0,05$ so there is no correlation between the pathogenicity of the isolates and the geographical origin of this isolates (Table 5).

Table 5: Student's t Test.

\begin{tabular}{|c|c|c|}
\hline Level & Least Sq Mean & Std Error \\
\hline Bechar & $98,00 \mathrm{a}$ & 13,54 \\
\hline Touat & $75,56 \mathrm{a}$ & 6,38 \\
\hline Ghardaïa & $74,63 \mathrm{a}$ & 6,77 \\
\hline
\end{tabular}

\section{Discussion}

Pathogenicity testing is the only way to determine the pathological effect of fungal strains present in diseased plants or in soil samples [21], this pathogenicity in the species Fusarium oxysporum led to the definition of special forms theoretically subservient, each with a single host plant, these forms are morphologically identical, but sometimes have very narrow parasitic specificity, each has a single host plant, these forms are morphologically identical, but sometimes have a very narrow parasitic specificity, unfortunately in the species Fusarium oxysporum, the variability of pathogenicity has been little studied $[22,23]$.

Currently, the identification of pathogenic Fusarium oxysporum isolates is mainly based on pathogenicity tests [24]. In our work the high mortality rate was recorded in seedlings inoculated with the 20 isolates of Foa, result confirming their belonging to the special form albedinis, compared to control seedlings, these results also coincide with those reported by several authors who mention the pathogenicity of Foa isolates against date palm seedlings [25-27].

The results obtained showed that there is no correlation between the pathogenicity of the isolates and the geographical origin of the isolate or cultivar from which this isolates were isolated, this result is similar to that reported by [28]. In addition, [29] reported that Fusarium species isolated from some parts of Europe were not able to cause the same levels of infection under different agroecological conditions.

The observation of brown necrosis in the roots of seedlings palms after inoculation, it's an indicator of the passage of Foa mycelium in vascular tissues, and these results correspond to those published by [30]. We then observed that the periphery of these roots was characterized by brown spots, resulting in the secretion of phenolic compounds against Foa, and this after the realization of the histological sections. Knowing that, the phenolic compounds involved in Bayoud resistance are documented [31, 32].

Studies related to the production of enzymes by a phytopathogenic fungus are complicated, particularly because of the presence of plant enzymes and microbial enzyme inhibitors, which occur in plants. Indeed, the enzymatic activity was tested for the first time by [33]. Currently, the most practical way to study the production of enzymes by a fungus is to study their production on artificial growth media, which contain no inhibitors [34].

Phytopathogenic fungi are responsible for significant plant damage and cause greater yield losses than bacteria and viruses [35], due to wide range of hydrolytic enzymes secreted during host plant infection, which will allow fungal cells to enter host plant cells by breaking down cell walls and causing pathogenesis in the host plant. It's the case, for example, of the species Fusarium oxysporum which excretes cellulases responsible for the hydrolysis of the plant cell wall $[19,36]$.

In our work, it was noted that all Foa isolates produce cellulase and amylase, with the development of a clear zone around the isolates, production vary between isolates depending on the diameter of the lysis zone. This result is comparable to those published by [15], and that of [20], which reported that $81 \%$ of fungal strains produce cellulase and $66.7 \%$ produce amylase.

\section{Conclusion}

After our study, our results showed the absence of correlation between the geographical origin and the pathogenicity of the isolates. As well, all this isolate was able to produce the hydrolytic enzymes on selective media used, with a strong positive correlation between mortality rate and amylolytic activity and a weak correlation with cellulase.

\section{Acknowledgement}

None

\section{Conflict of interest}

No conflict of interest.

\section{References}

1. Dransfield J, Uhl NW, Amussen CB, Baker WJ, Harley M, et al. (2008) Genera Palmarum: The evolution and classification of palms. Royal Botanic Gardens, Kew publishing, Kew, UK.

2. Salem AOM, Trifi M, Sakka H, Rhouma A, Marrakchi M (2001) Genetic inheritance analysis of four enzymes in date-palm (Phoenix dactylifera L.). Genetic Resources and Crop Evolution 48(4): 361-368.

3. Benabbes R, lahmass I, Souna F, El Youbi M, Saalaoui E, et al. (2015) In vitro inhibitory effect of the extract powder of Rosemary (Rosmarinus officinalis), Oleander (Nerium oleander), Grenadier (Punica granatum) on the growth of Fusarium oxysporum f.sp. albedinis and in vivo test antagonist fungi on the incidence and the control of vascular wilt disease of date palm in palm grove in Figuig South of Morocco. Adv Environ Biol 9(8): 126-132.

4. Al Antary TM, Al-Khawaldeh MM, Ateyyat MA (2015) Economic importance of date palm Phoenix dactylifera L. (Liliopsida: Arecales: Arecaceae) pests in Jordan Valley. Brazilian Journal of Biological Sciences 2(3): 121-134.

5. El kinany S, Achbani ElH, Haggoud A, Ibijbijen J, Belmalha S, et al. (2017) In vitro evaluation of compost extracts efficiency as biocontrol agent of date palm Fusarium wilt. African Journal of Microbiology Research 11(29): 1155-1161.

6. Bentrad N, Gaceb-Terrak R, Rahmania F (2017) Identification and evaluation of antibacterial agents present in lipophilic fractions isolated from sub-products of Phoenix dactilyfera. Nat Prod Res 31(21): 25442548. 
7. Trifi M, Rhouma A, Marrakchi M (2000) Phylogenetic relationships in Tunisian date-palm (Phoenix dactylifera L.) germplasm collection using a DNA amplification fingerprinting. Agronomie 20: 665-671.

8. El Modafar C (2010) Mechanisms of date palm resistance to Bayoud disease: Current state of knowledge and research prospects. Physiological and Molecular Plant Pathology 74: 287-294.

9. Abdullah SK, Lopez Lorca LV, Jansson HB (2010) Diseases of date palms (Phoenix dactylifera L.). Basrah Journal for Date Palm Researches 9(2): $1-43$

10. Benabbes R, lahmass I, Souna F, Chafi A, El Youbi M, et al. (2015) Confrontation of antagonistic fungi selected from the soil of the Figuig oasis to date palm Fusarium oxysporum f.sp. albedinis. Moroccan J Biol 12: $1-8$.

11. Djerbi M, Aouad L, Filali H, Saaidi M, Chtioui A, et al. (1986) Preliminary results of selection of high quality Bayoud resistant clones among natural date palm population in Morocco. The second symposium on the date palm, Saudi Arabia, 11: 383 - 399.

12. Sidaoui A, Karkachi N, Bertella A, Boudeffeur S, Chhiba M, et al. (2017) Morphological study and Caracterisation of Fusarium oxysporum f.sp. albedinis. by Isozymes systems. International Journal of Scientific \& Engineering Research 8(1): 1764-1768.

13. Sidaoui A, Karkachi N, Bertella A, El Goumi Y, Haouhach S, et al. (2018) Pathogenicity and biological control of Bayoud disease by Trichoderma longibrachiatum and Artemisia herba-alba essential oil. Journal of Applied Pharmaceutical Science 8(4): 161-167.

14. Tatsinkou FB, Taveai F, Ndjouenkeui R (2005) Production and partial characterization of a thermostable amylase from ascomycetes yeast strain isolated from starchy soils. African Journal of Biotechnology 4(1): 14-18.

15. Sunitha VH, Nirmala Devi D, Srinivas C (2013) Extracellular enzymatic activity of endophytic fungal strains isolated from medicinal plants. World Journal of Agricultural Sciences 9(1): 1-9.

16. Gopinath SCB, Anbu P, Hilda A (2005) Extracellular enzymatic activity profiles in fungi isolated from oil-rich environments. Mycoscience 46(2): 119-126.

17. Gopinath SCB, Anbu P, Arshad MK Md, Lakshmipriya T, Voon CH, et al. (2017) Biotechnological Processes in Microbial Amylase Production. BioMed Research International 2017: 1-9.

18. Lekchiri S, Moueqqit M, Lekchiri M, Lekchiri A (2013) Mise en évidence d'une activité cellulase chez Fusarium oxysporum f.sp. albedinis induite par une nouvelle forme d'hydrocellulose purifiée. Rev Microbio. Ind San et Environn 7(1): 88-97.

19. Bedade DK, Singhal RS, Turunen O, Deska J, Shamekh S (2017) Biochemical Characterization of Extracellular Cellulase from Tuber maculatum Mycelium Produced Under Submerged Fermentation. Appl Biochem Biotechnol 181(2): 772-783.

20. Ogórek R (2016) Enzymatic activity of potential fungal plant pathogens and the effect of their culture filtrate on seed germination and seedling growth of garden cress (Lepidium sativum L.). Eur J Plant Pathol 145(2): 469-481.

21. Gupta VK, Misra AK, Gaur R, Pandey R, Chauhan UK (2009) Studies of genetic polymorphism in the isolates of Fusarium solani. Aust J Crop Sci 3(2): 101-106.
22. Henni JE, Boisson C, Geiger JP (1994) Variabilité du pouvoir pathogène chez Fusarium oxysporum f. sp. lycopercisi. Phytopathol Medit 33: 10-16.

23. Sghir F, Touati J, Mouria B, Touhami AO, Filali-Maltouf A, et al. (2016) Variation in pathogenicity of Fusarium oxysporum f. sp. albedinis on two cultures associated with date palm of Moroccan oasis. World Journal of Pharmaceutical and Life Sciences 2(3): 56-68.

24. Lievens B, Rep M, Thomma BPHJ (2008) Recent developments in the molecular discrimination of formae speciales of Fusarium oxysporum. Pest Manag Sci 64(8): 781-788.

25. Mathéron B, Benbadis A (1994) Etude comparée de l'infection par le Fusarium oxysporum f. sp. albediniis, de trois variétés de palmier dattier, l'une sensible (Deglet-Nour), les deux autres résistantes (Takerboucht et Tantabouchet). Acta bot Gallica 141: 719 - 730.

26. Karkachi N, Gharbi S, Kihal M, Henni JE (2014) Study of pectinolytic activity of Fusarium oxysporum f.sp. albedinis agent responsible for bayoud in Algeria. IJAAR 5(2): 40-45.

27. Oubraim S, Sedra MH, Lazrek HB (2016) A relationship between Bayoud disease severity and toxin susceptibility of date palm cultivars. Emir J Food Agric 28(1): 45-51.

28. Sedra MH (1993) Remarques sur le pouvoir pathogène des isolats de Fusarium oxysporum f.sp. albedinis, agent de la fusariose vasculaire (Bayoud) de palmier dattier. Al Awamia 83: 223-239.

29. Brennan JM, Fagan, B, Van Maanen A (2003) Studies on in vitro growth and pathogenicity of European Fusarium fungi. European Journal of Plant Pathology 109(6): 577-587.

30. Azouaoui-Ait Kettout T, Rahmania F (2013) Contribution à l'étude de l'activité toxique de Fusarium oxysporum f. sp. albedinis, agent causal du Bayoud. Algerian journal of arid environment 3(1): 68-81.

31. El Hadrami I, Ramos T, Macheix JJ (1996) Caractérisation de nouveaux dérives hydroxycinnamiques amines chez Phoenix dactylifera L.: relation avec le brunissement des tissus et la résistance des cultivars au Bayoud. Polyphenols Comm 2: 341-342.

32. Daayf F, El Bellaj M, El Hassni M, J’Aiti F, El Hadram I (2003) Elicitation of soluble phenolics in date palm (Phoenix dactylifera) callus by Fusarium oxysporum f. sp. albedinis culture medium. Environmental and Experimental Botany 49: 41-47

33. Hankin L, Anagnostakis SL (1975) The use of solid media for detection of enzyme production by fungi. Mycology 67: 597 - 607

34. Moreira FG, Dos Reis S, Costa MAF, De Souza CGM, Peralta RM (2005) Production of hydrolytic enzymes by the plant pathogenic fungus Myrothecium verrucaria in submerged cultures. Brazilian Journal of Microbiology 36(1): 7-11.

35. Sexton AC, Howlett BJ (2006) Parallels in fungal pathogenesis on plant and animal hosts. Eukaryotic Cell 5(12): 1941-1949.

36. Cheilas T, Stoupis T, Christakopoulos P, Katapodis P, Mamma D, et al (2000) Hemicellulolytic activity of Fusarium oxysporum grown on sugar beet pulp. Production of extracellular arabinanase. Process Biochem 35(6): 557-561. 